\title{
Users’ Behaviour on Facebook: A Literature Review
}

\author{
Shuaa Aljasir ${ }^{1}$, Ayman Bajnaid ${ }^{1}$, Tariq Elyas ${ }^{2} \&$ Mustafa Alnawasrah ${ }^{3}$ \\ ${ }^{1}$ Faculty of Media and Communication, Communication Department, King Abdulaziz University, Jeddah, Saudi \\ Arabia \\ ${ }^{2}$ European Languages Department, King Abdulaziz University, Jeddah, Saudi Arabia \\ ${ }^{3}$ Faculty of Business \& Finance, Business Administration Department, The World Islamic Science \& Education \\ University, Amman, Jordan \\ Correspondence: Shuaa Aljasir, Faculty of Media and Communication, Communication Department, King Abdulaziz \\ University, Jeddah, Saudi Arabia. E-mail: shaljasir@kau.edu.sa
}

Received: October 27, 2017

Accepted: November 8, 2017

Online Published: November 16, 2017

doi:10.5430/ijba.v8n7p111

URL: https://doi.org/10.5430/ijba.v8n7p111

\begin{abstract}
This paper presents a literature review focused solely on research about users' behaviour on Facebook. It reviews studies that have examined obtained gratifications from using Facebook, followed by a section that discusses studies concerning status updates; and then reviews studies of self-disclosure. It finally reviews studies that have investigated gender differences on Facebook. The conclusion of this paper highlights the gaps in the literature regarding users' behaviour on Facebook.
\end{abstract}

Keywords: users' behaviour, Facebook, literature review, technology adoption

\section{Introduction}

As Facebook becomes more integrated into individuals' everyday lives (Lin, Fan, \& Chau, 2014; Maqableh, Rajab, Quteshat \& Karajeh, 2015; Khwaldeh, Al-Hadid, \& Alrowwad, 2017), scholars from different cultures (e.g. the United States, Canada, the United Kingdom, Turkey, South Africa, Somalia, China, Korean, Hong Kong, Taiwan, Singapore, Malaysia, India, and Iran) have investigated Facebook users' behaviour. The current paper focuses on studies related to the following five areas.

\subsection{Overview of Previous Studies of Facebook-Obtained Gratifications}

In the 1930s and 1940s, the predominant view of the relationship between audiences and media was that media tools directly and identically affected all audiences, who were generally viewed as naïve, inactive, and powerless to resist the intended effects of such media. This view is reflected in theories such as the 'Magic Bullet Theory' or 'Hypodermic Needle Theory' (Kumar \& Thapa, 2014). Such perspective has been criticised for asserting that the media injects information into a passive audience, who has a minimal role in interpreting its content (Quan-Haase, 2012). Meanwhile, uses and gratifications theory has emerged as a counter-perspective on the relationship between media and its respective audiences, shifting the focus from what the media does to individuals to what individuals do with the media (Rubin 1994). Although it has attracted a great deal of attention, scholars are not certain about when this theory emerged (Ruggiero, 2000). Wimmer and Dominick (2011) date its origins to the 1940s, when scholars started to consider why audiences became involved in various forms of media behaviour, such as listening to radio programs and reading newspapers. Blumler and Katz (1940) are often cited as the creators of the theory. In this early stage, uses and gratifications research was simple and descriptive, attempting only to group participants' statements regarding their expected gratifications into themes. It failed to identify the possible variables affecting audiences' gratifications (McQuail, 1998).

To overcome this limitation, uses and gratifications research in the 1950s and 1960s (referred to as the second stage of uses and gratifications theory) started to identify the potential variables that might make individuals seek different gratifications from a media tool, such as social class or cultural background (Ruggiero, 2000). The scope of uses and gratifications theory was articulated by Katz (1959) in this stage. Katz (1959) indicated that even the most effective media content has no significant impact on individuals who have no use for it. He 
also posited that individuals have the ability to select what they see and hear according to their desires and needs, with their values, interests, associations, and social roles playing a significant part in altering these desires and needs. Nevertheless, uses and gratifications research during its second stage was limited in concentrating only on the needs individuals sought to gratify from utilising the media, ignoring their actual outcomes or obtained gratifications (Wimmer \& Dominick, 2011).

In the 1970s (considered the third stage of uses and gratifications theory), researchers altered their focus to gratifications obtained from a media tool and the impact of obtaining these gratifications on strengthening or weakening the connection with self, family, or society (Rubin, 1994). Katz, Blumler, and Gurevitch (1974: 515-517) articulated the following five fundamental assumptions during this stage to strengthen the theoretical frame: 1. Audiences are active, 2. "Much of the initiative in linking need gratification and media choice lies with the audience member", 3. Audiences have diverse needs that can be satisfied in different ways and media tools compete to be the source of this satisfaction, 4. Audiences are aware of their needs and self-reporting methods provide accurate data about media use, and 5. "Value judgments about the cultural significance of mass communication should be suspended while audience operations are explored on their own terms". At this stage of uses and gratifications research, it was believed that the focus should be exclusively on determining the value of media content and that studying the cultural implications of that content should be postponed until a solid understanding of gratifications had been formed.

In their continued attempts to refine the theory, scholars in the 1980s made systematic attempts to replicate or expand upon previous research, improve its methodology, comparatively analyse the results of separate studies (Rubin, 1983; Wimmer \& Dominick, 2011) and re-evaluate its long-held assumptions, such as the notion that audiences are active (Ruggiero, 2000). For instance, Rubin (1984) argued that audiences' agency should not be taken for granted and their level of activity should be viewed as more variable than absolute along a continuum from passivity to activity. Thus, audience activity is affected by media content and is based on rational decision making and assessment of content (Rubin, 2009).

In the fourth stage of the development of the theory during the 1990s, Rubin (1994) revised Katz, Blumler, and Gurevitch's (1974) assumptions to provide a contemporary view of uses and gratifications theory. He echoed Katz, Blumler, and Gurevitch's (1974) assumptions that audiences are active and purposive in selecting and using media tools to their advantage. He argued that "individuals' communicational behaviour, including the selection and use of the media, is goal-directed, purposive". His second assumption indicated that "individuals initiate the selection and use of communication and media tools. Instead of being used by the media, individuals select and use media to satisfy their felt needs or desires" (Rubin, 1994: 428).

The third assumption stated that several factors "guide, filter or mediate media and communication behaviour" (Rubin, 1994: 428). This assumption acknowledged the role of external and internal factors in affecting individuals' behaviours. Extending Katz, Blumler, and Gurevitch's (1974) assumption that media tools compete to be the source of the satisfaction, Rubin's fourth assumption stated that "the media compete with other forms of media, or functional alternatives such as interpersonal interaction, for selection, attention, and use, so that individuals can gratify their needs or wants" (Rubin, 1994: 428). The fifth assumption indicated that "individuals are typically more influential than the media, but not always" (Rubin, 1994: 428). While Rubin confirms in this assumption the notion that individuals' influence supersedes that of the media, he does not exclude the possibility that media sources may have an impact on individuals or society's social, political, cultural, or economic structures.

While excluding it from his contemporary view of uses and gratifications, Rubin (1994) commented on the fourth assumption described by Katz, Blumler, and Gurevitch (1974) regarding the reliance on self-reporting, pointing out that while self-report scales have been shown to be consistent and accurate, uses and gratifications researchers were also using experimental, ethnographic, and diary/narrative methods to develop and extend conceptual, focused, and systematic lines of uses and gratifications inquiry. Commenting on the fifth assumption proposed by Katz, Blumler and Gurevitch (1974), Rubin (1994) also indicated that with a clearer understanding of the gratifications in the present uses and gratifications literature, it is time to include questions relating to cultural issues. Following this recommendation, media and communication research in general and uses and gratifications research in particular started to combine media and cultural studies, highlighting the role of the cultural context in influencing individuals' interactions with the media.

The fifth and current phase of uses and gratifications theory began in the late 1990s with the increased interest in Internet studies. Ruggiero (2000) argues that the Internet possesses at least three characteristics not usually 
linked to traditional media, which makes it amenable to study using uses and gratifications theory: First, it is interactive, providing new means of communication and opportunities to engage in a range of online activities. Second, the Internet is characterised as being de-massifying because it enables users to select from a wide range of media content and alter content according to their needs. Third, it is distinguished by its asynchroneity, which enables users to send, receive, save, or retrieve messages on their own time schedule. Ruggiero (2000) indicates that these features are in line with uses and gratifications theory's fundamental assumption that media audiences are active in initiating and using a media tool and the idea that they influence the content of the media they use more than they are affected by the media.

In this current phase, researchers emphasise the need to modify uses and gratifications theory's concepts of 'active' and 'audience' to be more accurate and applicable to Internet studies. It is argued that in the case of Internet usage, all users are active but they have different levels of activity (Dicken-Garcia, 1998). For instance, some Internet users are highly active and goal-directed in their usage, while others may only use the Internet out of curiosity or for entertainment. Uses and gratifications scholars also indicate that the traditional concept of 'audience' should be altered to encompass individuals' interactive roles. As Internet technology includes several text, audio, and video services that converge into one medium that is used to gratify multiple needs, scholars have started to replace the term 'audience' with 'users' (Wimmer \& Dominick, 2011).

Ruggiero (2000) asserts that uses and gratifications theory can provide 'a cutting-edge theoretical approach' in the early stages of every new media source: newspapers, radio, television, and lately the Internet. He recommends that uses and gratifications theory be used when predicting the future of a media tool. Considering that social media platforms are among the latest media tools to be utilised by individuals, scholars have increasingly adopted uses and gratifications theory when investigating these platforms in general and Facebook in particular. Table 1 provides an overview of the previous studies of Facebook-obtained gratifications.

Table 1. Previous Facebook-obtained gratifications studies

\begin{tabular}{|c|c|c|c|c|c|c|}
\hline Authors & Year & Nation & Scope & Methods & Participants & Obtained Gratifications \\
\hline Bumgarner & 2007 & USA & $\begin{array}{l}\text { The uses and gratifications } \\
\text { obtained from Facebook }\end{array}$ & $\begin{array}{l}\text { Online } \\
\text { questionnaire }\end{array}$ & $1049 *$ & $\begin{array}{l}\text { 1. diversion; 2. personal expression; } 3 \text {. } \\
\text { collection and connection; } 4 \text {. directory; } \\
\text { 5. voyeurism; } 6 \text {. social utility; } 7 \text {. herd } \\
\text { instinct; } 8 \text {. initiating relationships }\end{array}$ \\
\hline Foregger & 2008 & USA & $\begin{array}{l}\text { The gratifications obtained } \\
\text { from Facebook }\end{array}$ & Questionnaire & $\begin{array}{l}340(122 \\
\text { males, } 214 \\
\text { females, } 4 \\
\text { unknown) }\end{array}$ & $\begin{array}{l}\text { 1. pass time; } 2 \text { connection; } 3 . \text { sexual } \\
\text { attraction; } 4 \text {. utilities and upkeeps; } 5 \text {. } \\
\text { establish/maintain old ties; } 6 . \\
\text { accumulation; } 7 . \text { social comparison; } 8 \text {. } \\
\text { channel use and networking }\end{array}$ \\
\hline Joinson & 2008 & $\begin{array}{l}\text { Online } \\
\text { sample }\end{array}$ & $\begin{array}{l}\text { The uses and gratifications } \\
\text { obtained from Facebook }\end{array}$ & $\begin{array}{l}\text { Online } \\
\text { questionnaire }\end{array}$ & $\begin{array}{l}241 \text { ( } 80 \text { males, } \\
161 \text { female) }\end{array}$ & $\begin{array}{l}\text { 1. connection, } 2 \text {. shared identities, } 3 \text {. } \\
\text { photographs, } 4 \text {. content, } 5 \text {. social } \\
\text { investigation, } 6 . \text { social network surfing } \\
\text { 7. status updating }\end{array}$ \\
\hline $\begin{array}{l}\text { Raacke \& } \\
\text { Bonds-Raacke }\end{array}$ & 2008 & USA & $\begin{array}{l}\text { The gratifications obtained } \\
\text { from Facebook and Myspace }\end{array}$ & Questionnaire & $\begin{array}{l}116 \text { ( } 53 \text { males, } \\
63 \text { females })\end{array}$ & $\begin{array}{l}\text { 1. keep in touch with old } \\
\text { friends; } 2 \text {. keep in touch with current } \\
\text { friends; } 3 \text {. post/look at pictures; } 4 \text {. make } \\
\text { new friends; } 5 \text {. locate old friends; } 6 \text {. } \\
\text { learn about events; } 7 \text {. post social } \\
\text { functions; } 8 \text {. feel connected; } 8 . \text { share } \\
\text { information about oneself; } 9 \text {. for } \\
\text { academic purposes; } 10 \text {. for dating } \\
\text { purposes }\end{array}$ \\
\hline Sheldon & 2008 & USA & $\begin{array}{l}\text { The influence of } \\
\text { unwillingness-to-communicate } \\
\text { on gratifications sought and } \\
\text { obtained from Facebook }\end{array}$ & Questionnaire & $\begin{array}{l}172 \text { (74 males, } \\
98 \text { females) }\end{array}$ & $\begin{array}{l}\text { 1. relationship maintenance; } 2 \text {.passing } \\
\text { time; } 3 \text {. virtual community; } \\
\text { 4.entertainment; } 5 \text {. coolness; } 6 \text {. } \\
\text { companionship }\end{array}$ \\
\hline $\begin{array}{l}\text { Urista, Dong } \\
\text { \& Day }\end{array}$ & 2009 & USA & $\begin{array}{l}\text { The gratifications obtained } \\
\text { from Facebook and Myspace }\end{array}$ & Focus groups & $50^{*}$ & $\begin{array}{l}\text { 1. efficient communication, } 2 \text {. } \\
\text { convenient communication, } 3 \text {. curiosity }\end{array}$ \\
\hline
\end{tabular}




\begin{tabular}{|c|c|c|c|c|c|c|}
\hline Authors & Year & Nation & Scope & Methods & Participants & Obtained Gratifications \\
\hline & & & & & & $\begin{array}{l}\text { about others, } 4 \text {. popularity } 5 \text {. } \\
\text { relationship formation reinforcement }\end{array}$ \\
\hline $\begin{array}{l}\text { Bonds-Raacke } \\
\text { \& Raacke }\end{array}$ & 2010 & USA & $\begin{array}{l}\text { The uses and gratifications } \\
\text { obtained from Facebook and } \\
\text { Myspace }\end{array}$ & Questionnaire & $\begin{array}{l}201 \text { (63 males, } \\
138 \text { females) }\end{array}$ & $\begin{array}{l}\text { 1. information, 2. friendship } 3 . \\
\text { connection }\end{array}$ \\
\hline $\begin{array}{l}\text { Gülnar, Balcı } \\
\text { \& Çakır }\end{array}$ & 2010 & Turkey & $\begin{array}{l}\text { The gratifications obtained } \\
\text { from Facebook, YouTube and } \\
\text { other social media platforms }\end{array}$ & Questionnaire & $\begin{array}{l}500(282 \\
\text { males, } 218 \\
\text { females })\end{array}$ & $\begin{array}{l}\text { 1. narcissism and self-expression; } 2 . \\
\text { media drenching and performance; } 3 \text {. } \\
\text { passing time; } 4 \text {. information seeking; } 5 \text {. } \\
\text { personal status; } 6 . \text { relationship } \\
\text { maintenance; } 7 \text {. entertainment }\end{array}$ \\
\hline $\begin{array}{l}\text { Quan-Haase } \\
\& \text { Young }\end{array}$ & 2010 & Canada & $\begin{array}{l}\text { The gratifications obtained } \\
\text { from Facebook and instant } \\
\text { messaging }\end{array}$ & $\begin{array}{l}\text { Questionnaire } \\
\text { and interview }\end{array}$ & $\begin{array}{l}77 \text { for the } \\
\text { questionnaire } \\
\text { ( } 21 \text { males, } 56 \\
\text { females) } \\
21 \text { for } \\
\text { Interviews (5 } \\
\text { males, } 16 \\
\text { females) }\end{array}$ & $\begin{array}{l}\text { 1. pastime; } 2 \text {. affection; } 3 \text {. fashion; } 4 \text {. } \\
\text { share problems; } 5 \text {. sociability; } 6 \text {. social } \\
\text { information }\end{array}$ \\
\hline $\begin{array}{l}\text { Cheung, Chiu } \\
\text { \& Lee }\end{array}$ & 2011 & $\begin{array}{l}\text { Online } \\
\text { Sample }\end{array}$ & $\begin{array}{l}\text { The gratifications obtained } \\
\text { from Facebook }\end{array}$ & $\begin{array}{l}\text { Online } \\
\text { questionnaire }\end{array}$ & $\begin{array}{l}182 \text { (58 males, } \\
124 \text { females) }\end{array}$ & $\begin{array}{l}\text { 1. social identify; } 2 \text {. purpose value; } 3 \text {. } \\
\text { self-discovery; } 4 \text {. maintaining } \\
\text { interpersonal interconnectivity; } 5 \text {. social } \\
\text { enhancement; } 6 \text {. entertainment value; } 7 \text {. } \\
\text { social presence }\end{array}$ \\
\hline $\begin{array}{l}\text { Kim, Sohn \& } \\
\text { Choi }\end{array}$ & 2011 & $\begin{array}{l}\text { Korea and } \\
\text { USA }\end{array}$ & $\begin{array}{l}\text { The uses and gratifications } \\
\text { obtained from Facebook }\end{array}$ & Questionnaire & $\begin{array}{l}349 \text { from USA } \\
\text { ( } 87 \text { males, } \\
262 \text { females) } \\
240 \text { from } \\
\text { Korea ( } 131 \\
\text { males, } 109 \\
\text { females) }\end{array}$ & $\begin{array}{l}\text { 1. seeking friends; } 2 \text {. social support; } 3 \text {. } \\
\text { entertainment; } 4 \text {. information; } 5 \text {. } \\
\text { convenience }\end{array}$ \\
\hline $\begin{array}{l}\text { Zhang, Tang } \\
\& \text { Leung }\end{array}$ & 2011 & $\begin{array}{l}\text { Hong } \\
\text { Kong }\end{array}$ & $\begin{array}{l}\text { The impacts of the } \\
\text { gratifications obtained and } \\
\text { psychological traits on } \\
\text { Facebook use }\end{array}$ & $\begin{array}{l}\text { Focus group } \\
\text { and } \\
\text { online } \\
\text { questionnaire }\end{array}$ & $\begin{array}{l}17 \text { (focus } \\
\text { group)* } \\
437(185 \\
\text { males, } 252 \\
\text { females) }\end{array}$ & $\begin{array}{l}\text { 1. social surveillance; } 2 \text {. entertainment; } \\
\text { 3. recognition; 4. emotional support; } 5 \text {. } \\
\text { network extension; } 6 \text {. maintenance }\end{array}$ \\
\hline $\begin{array}{l}\text { Alhabash et } \\
\text { al. }\end{array}$ & 2012 & Taiwan & $\begin{array}{l}\text { The gratifications obtained } \\
\text { from Facebook and how they } \\
\text { predict the intensity of } \\
\text { Facebook use and } \\
\text { content-generation behaviours }\end{array}$ & $\begin{array}{l}\text { Online } \\
\text { questionnaire }\end{array}$ & $\begin{array}{l}4346(1795 \\
\text { males, } 2551 \\
\text { females })\end{array}$ & $\begin{array}{l}\text { 1. social connection; } 2 \text {. shared } \\
\text { identities; } 3 \text {. photographs; } 4 \text {. contents; } 5 \text {. } \\
\text { social investigation; } 6 \text {. social network } \\
\text { surfing; } 7 \text {. status updates }\end{array}$ \\
\hline $\begin{array}{l}\text { Gadekar, } \\
\text { Krishnatray \& } \\
\text { Gaur }\end{array}$ & 2012 & India & $\begin{array}{l}\text { The uses and gratifications } \\
\text { obtained from Facebook }\end{array}$ & Questionnaire & $\begin{array}{l}455(268 \\
\text { males, } 187 \\
\text { females })\end{array}$ & $\begin{array}{l}\text { 1. relationship maintenance; } 2 \text {. } \\
\text { user-friendliness; } 3 \text {. relaxation; } 4 \text {. } \\
\text { connecting with old friends; } 5 \text {. social } \\
\text { interaction }\end{array}$ \\
\hline $\begin{array}{l}\text { Hew \& } \\
\text { Cheung }\end{array}$ & 2012 & Singapore & $\begin{array}{l}\text { The gratifications obtained } \\
\text { from Facebook, the types of } \\
\text { friends and privacy }\end{array}$ & $\begin{array}{l}\text { Online } \\
\text { questionnaire }\end{array}$ & $\begin{array}{l}83 \text { ( } 23 \text { males } \\
\text { and } 60 \\
\text { females })\end{array}$ & $\begin{array}{l}\text { 1. keeping in touch with friends; } 2 \text {. } \\
\text { entertainment; } 3 . \text { broadening the social } \\
\text { network; } 5 \text {. expressing emotions; } 6 \text {. } \\
\text { following the trend/crowd; } 7 \text {. for fun/for } \\
\text { the sake of having a Facebook account }\end{array}$ \\
\hline $\begin{array}{l}\text { Hunt, Atkin \& } \\
\text { Krishnan }\end{array}$ & 2012 & USA & $\begin{array}{l}\text { The influence of CMC } \\
\text { apprehension on the } \\
\text { gratifications obtained from } \\
\text { using Facebook }\end{array}$ & $\begin{array}{l}\text { Online } \\
\text { questionnaire }\end{array}$ & $\begin{array}{l}417(196 \\
\text { males, } 221 \\
\text { females) }\end{array}$ & $\begin{array}{l}\text { 1. interpersonal utility; } 2 . \\
\text { self-expression; } 3 \text {. entertainment; } 4 \text {. } \\
\text { passing time }\end{array}$ \\
\hline
\end{tabular}




\begin{tabular}{ccclcc}
\hline \multicolumn{1}{c}{ Authors } & Year & Nation & \multicolumn{1}{c}{ Scope } & Methods & Participants \\
\hline Tosun & 2012 & Turkey & $\begin{array}{l}\text { The gratifications obtained } \\
\text { from Facebook and expressing } \\
\text { true self on the Internet }\end{array}$ & $\begin{array}{l}\text { Online } \\
\text { questionnaire }\end{array}$ & $\begin{array}{l}143 \text { (37 males, } \\
106 \text { females) }\end{array}$
\end{tabular}

true self on the Internet

\begin{tabular}{|c|c|c|c|c|c|c|}
\hline $\begin{array}{l}\text { Wang, } \\
\text { Tchernev \& } \\
\text { Solloway }\end{array}$ & 2012 & USA & $\begin{array}{l}\text { The uses and gratifications } \\
\text { obtained from social media } \\
\text { including Facebook }\end{array}$ & Questionnaire & $\begin{array}{l}28 \text { ( } 11 \text { males, } \\
17 \text { females })\end{array}$ & $\begin{array}{l}\text { 1. emotional needs; } 2 \text {. cognitive needs; } \\
\text { 3. social needs; } 4 \text {. habitual needs }\end{array}$ \\
\hline Xu et al. & 2012 & USA & $\begin{array}{l}\text { The uses and gratifications } \\
\text { obtained from Facebook }\end{array}$ & $\begin{array}{l}\text { Focus group } \\
\text { and } \\
\text { questionnaire }\end{array}$ & $\begin{array}{l}148 \\
\text { (questionnaire) } \\
\text { ( } 81 \text { males, } 67 \\
\text { females) }\end{array}$ & $\begin{array}{l}\text { 1. coordination; } 2 \text {. disclosure; 3. escape; } \\
\text { 4. immediate access; } 5 \text {. leisure; } 6 \text {. } \\
\text { stylishness }\end{array}$ \\
\hline
\end{tabular}

\begin{tabular}{|c|c|c|c|c|c|c|}
\hline $\begin{array}{l}\text { Alemdar \& } \\
\text { Köker }\end{array}$ & 2013 & Turkey & $\begin{array}{l}\text { The gratifications obtained } \\
\text { from Facebook for } \mathrm{X} \text { and } \mathrm{Y}\end{array}$ & Interview & $11 *$ & $\begin{array}{l}\text { 1. social surveillance; 2. recognition; } 3 \\
\text { emotional support; } 4 \text {. social }\end{array}$ \\
\hline
\end{tabular}
generations

connectivity; 5 . entertainment; 6 . narcissism and self-expression; 7. ease to use; 8 . freedom and courage; 9 . adaptation to new challenges

\begin{tabular}{|c|c|c|c|c|c|c|}
\hline $\begin{array}{l}\text { Balakrishnan } \\
\text { \& Shamim }\end{array}$ & 2013 & Malaysia & $\begin{array}{l}\text { The uses and gratifications } \\
\text { obtained from Facebook, } \\
\text { psychological and behavioural } \\
\text { factors affecting the users }\end{array}$ & $\begin{array}{l}\text { Focus group } \\
\text { and } \\
\text { questionnaire }\end{array}$ & $\begin{array}{l}12 \text { (focus } \\
\text { group)* } \\
707 \\
\text { (questionnaire) } \\
\text { (324 males, } \\
383 \text { females) }\end{array}$ & $\begin{array}{l}\text { 1. social networking; } 2 \text {. psychological } \\
\text { benefits; } 3 \text {.entertainment, } \\
\text { 4.self-presentation; } 5 \text {. skill enhancement }\end{array}$ \\
\hline Chigona & 2013 & $\begin{array}{l}\text { South } \\
\text { Africa }\end{array}$ & $\begin{array}{l}\text { The gratifications sought and } \\
\text { obtained from Facebook and } \\
\text { the factors influencing } \\
\text { continued usage }\end{array}$ & Interviews & $\begin{array}{l}8 \text { ( } 4 \text { males, } 4 \\
\text { females) }\end{array}$ & $\begin{array}{l}\text { 1. keeping in touch with friends; } 2 \text {. } \\
\text { diversion (escape) and entertainment } \\
\text { and pass time; } 3 \text {. find friends from past } \\
\text { relationships by using the friends search } \\
\text { function; } 4 \text {. voyeurism; } 5 \text {. } \\
\text { self-expressing; } 5 \text {. social utility }\end{array}$ \\
\hline $\begin{array}{l}\text { Dhaha \& } \\
\text { Igale }\end{array}$ & 2013 & Somalia & $\begin{array}{l}\text { The gratifications obtained } \\
\text { from Facebook }\end{array}$ & $\begin{array}{l}\text { Online } \\
\text { questionnaire }\end{array}$ & $\begin{array}{l}311(271 \\
\text { males } 40 \\
\text { females })\end{array}$ & $\begin{array}{l}\text { 1. virtual companionship and escape; } 2 \text {. } \\
\text { interpersonal entertainment; } 3 \text {. } \\
\text { self-description of own country; } 4 \text {. } \\
\text { self-expression; } 5 \text {. information seeking; } \\
6 \text {. passing time }\end{array}$ \\
\hline $\begin{array}{l}\mathrm{Ku}, \text { Chen \& } \\
\text { Zhang }\end{array}$ & 2013 & $\begin{array}{l}\text { USA and } \\
\text { Taiwan }\end{array}$ & $\begin{array}{l}\text { The gratifications obtained } \\
\text { from Facebook and their effect } \\
\text { on the continued use of } \\
\text { Facebook }\end{array}$ & $\begin{array}{l}\text { Interview } \\
\text { and } \\
\text { questionnaire }\end{array}$ & $\begin{array}{l}\text { For the } \\
\text { Interview: } \\
10 \text { from USA } \\
\text { and } 10 \text { from } \\
\text { Taiwan* } \\
\text { For the } \\
\text { questionnaire: } \\
103 \text { from USA } \\
\text { ( } 64 \text { males, } 39 \\
\text { females) and } \\
122 \text { from } \\
\text { Taiwan (53 } \\
\text { males, } 69 \\
\text { females) }\end{array}$ & $\begin{array}{l}\text { 1. information; } 2 \text {. entertainment; } 3 \text {. } \\
\text { fashion; } 4 \text {. sociability; } 5 \text {. relationship } \\
\text { maintenance }\end{array}$ \\
\hline $\begin{array}{l}\text { Kwon, } \\
\text { D'Angelo }\end{array}$ & 2013 & USA & $\begin{array}{l}\text { The uses and gratifications } \\
\text { obtained from Facebook and }\end{array}$ & $\begin{array}{l}\text { Online } \\
\text { questionnaire }\end{array}$ & $\begin{array}{l}152 \text { (47 males, } \\
105 \text { females) }\end{array}$ & $\begin{array}{l}\text { 1. information seeking; } 2 \text {. } \\
\text { entertainment; 3. communication; } 4 \text {. }\end{array}$ \\
\hline
\end{tabular}




\begin{tabular}{lcclcc}
\hline \multicolumn{1}{c}{ Authors } & Year & Nation & \multicolumn{1}{c}{ Scope } & Methods & Participants \\
\hline \& McLeod & & & $\begin{array}{l}\text { their link to bridging and } \\
\text { bonding social capital }\end{array}$ & \\
\hline $\begin{array}{l}\text { Jackson \& } \\
\text { Wang }\end{array}$ & 2013 & $\begin{array}{l}\text { China and } \\
\text { USA }\end{array}$ & $\begin{array}{l}\text { The uses and gratifications } \\
\text { obtained from Facebook }\end{array}$ & Questionnaire & 400 (USA)* \\
490 (China) $^{*}$
\end{tabular}

social relations; 5 . escape; 6 . Facebook

applications

1. keeping in touch with parentsand

other family members; 2 . keeping in

touch with friends; 3 . connecting with people known but rarely seen; 4 . meeting new people; 5.obtaining information

\begin{tabular}{lllllll}
\hline Pai \& Arnott & 2013 & Taiwan & $\begin{array}{l}\text { The gratifications obtained } \\
\text { from Facebook }\end{array}$ & Interview & $\begin{array}{l}24 \text { (13 males, } \\
11 \text { females })\end{array}$ & $\begin{array}{l}\text { 1. belonging; } 2 . \text { hedonism; } 3 . \\
\text { self-esteem; 4. reciprocity }\end{array}$ \\
\hline $\begin{array}{l}\text { Patra, } \\
\text { Gadekar, \& }\end{array}$ & 2013 & India & $\begin{array}{l}\text { The relationship between uses, } \\
\text { gratifications obtained from }\end{array}$ & Questionnaire & $550 *$ & $\begin{array}{l}\text { 1. relationship maintenance; 2. } \\
\text { Krishnatray }\end{array}$ \\
& & $\begin{array}{l}\text { Facebook, and personality } \\
\text { traits }\end{array}$ & & $\begin{array}{l}\text { usendliness; 3. relaxation; } 4 \\
\text { connecting with old friends }\end{array}$
\end{tabular}

\begin{tabular}{|c|c|c|c|c|c|}
\hline $\begin{array}{l}\text { Whiting \& } \\
\text { Williams }\end{array}$ & 2013 & USA & $\begin{array}{l}\text { The gratifications obtained } \\
\text { from Facebook }\end{array}$ & Interview & $\begin{array}{l}25 \text { (13 males, } \\
12 \text { females) }\end{array}$ \\
\hline
\end{tabular}

1. social interaction; 2 . information seeking; 3 . pass time; 4. entertainment, relaxation; 5.communicatory utility; 6 . convenience utility; 7. expression of opinion; 8. information sharing; 9. surveillance/knowledge about others

\begin{tabular}{|c|c|c|c|c|c|c|}
\hline $\begin{array}{l}\text { Yang \& } \\
\text { Brown }\end{array}$ & 2013 & USA & $\begin{array}{l}\text { The relationship between uses, } \\
\text { gratifications obtained from } \\
\text { Facebook, and social } \\
\text { adjustment }\end{array}$ & Questionnaire & $\begin{array}{l}193 \text { ( } 89 \text { males, } \\
104 \text { female) }\end{array}$ & $\begin{array}{l}\text { 1. relationship formation; } 2 \text {. relationship } \\
\text { maintenance }\end{array}$ \\
\hline $\begin{array}{l}\text { Alhabash, } \\
\text { Chiang, \& } \\
\text { Huang }\end{array}$ & 2014 & Taiwan & $\begin{array}{l}\text { The relationship between the } \\
\text { gratifications obtained from } \\
\text { Facebook and the continuity to } \\
\text { use it }\end{array}$ & $\begin{array}{l}\text { Online } \\
\text { questionnaire }\end{array}$ & $\begin{array}{l}3172(1576 \\
\text { males, } 1596 \\
\text { females })\end{array}$ & $\begin{array}{l}\text { 1. information sharing; } 2 \text {. } \\
\text { self-documentation; } 3 \text {.social interaction; } \\
\text { 4.entertainment; 5. passing time; } 6 \text {. } \\
\text { self-expression; } 7 \text {. medium appeal }\end{array}$ \\
\hline Karimi et al. & 2014 & $\begin{array}{l}\text { Iranian, } \\
\text { Malaysian, } \\
\text { British, } \\
\text { and South } \\
\text { African }\end{array}$ & $\begin{array}{l}\text { The gratifications obtained } \\
\text { from Facebook }\end{array}$ & $\begin{array}{l}\text { Online and } \\
\text { hand-delivered } \\
\text { questionnaires }\end{array}$ & $\begin{array}{l}320(74 \\
\text { Malaysian, } 96 \\
\text { Iranian, } 61 \\
\text { UK, } 89 \text { South } \\
\text { African)* }\end{array}$ & $\begin{array}{l}\text { 1. interpersonal utility; } 2 \text {. pass time; } 3 \text {. } \\
\text { entertainment; } 4 \text {. information seeking; } \\
\text { 5. convenience }\end{array}$ \\
\hline
\end{tabular}

\footnotetext{
* does not indicate numbers by genders
}

Table 1 reveals that scholars began studying the gratifications obtained from Facebook around three years after its launch and continue to the present day. Their studies have been carried out in many countries. The majority have been conducted among samples from United States, followed by samples from Asia, Turkey, and Africa. Cross-cultural studies have mainly compared American and Asian samples, with the exception of a study by Karimi et al. (2014) that was conducted among Iranian, Malaysian, British, and South African students. Although studies of Facebook-obtained gratifications involving university students have been taking place for almost a decade, no known study has been conducted on an Arabic sample.

Reviewing the rationale behind such increasing interest in studying the obtained gratifications from Facebook reveals that the majority of scholars have sought to uncover the gratifications obtained from using this social media platform in order to provide a better understanding of why users are highly engaged with its platform. Besides revealing the obtained gratifications, some scholars were concerned with the effects of these gratifications on users' intensity of Facebook use and their intentions to continue using its platform (i.e., Alhabash, et al. 2012; Chigona, 2013; Ku, Chen, \& Zhang, 2013; Alhabash, Chiang, \& Huang, 2014). The rest were interested in investigating these obtained gratifications in order to measure their impacts on some psychological or sociological variables such as expressing one's true self or social adjustment (i.e., Sheldon, 2008; Zhang, Tang, \& Leung, 2011; Hunt, Atkin \& Krishnan, 2012; Tosun, 2012; Balakrishnan \& Shamim, 2013; Kwon, D’Angelo, \& McLeod, 2013; Patra, Gadekar, \& Krishnatray, 2013; Yang \& Brown, 2013; Barreda et al., 2015; Alawaln et al., 2016; Bilgihan et al., 2017). 
A review of uses and gratifications studies indicates that they were in line with Ruggiero's (2000) methodological recommendations. According to Ruggiero (2000), the use of questionnaires is recommended in uses and gratifications research because they allow the quantification and rank ordering of gratifications. The majority of studies have utilised a questionnaire (online or offline), either alone or in combination with more qualitative methods. A few studies used exclusively qualitative methods, such as an interview or a focus group.

Reviewing the sample sizes reveals that quantitative sample sizes ranged from 28 participants to 4348 participants, and qualitative studies ranged from 8 to 50 participants. This means that the results of some of these studies should not be generalised beyond the student population or beyond the time and context of these studies because of the rapid expansion and diversification of Facebook usage. Some of the reviewed studies display a gender bias either towards females (i.e., Foregger, 2008; Joinson, 2008; Bonds-Raacke \& Raacke, 2010; Quan-Haase \& Young, 2010; Cheung, Chiu, \& Lee, 2011; Alhabash, et al. 2012; Hew \& Cheung, 2012; Tosun, 2012; Kwon, D’Angelo \& McLeod, 2013) or males (i.e., Dhaha \& Igale, 2013), which has been acknowledged as a limitation in most of these studies.

Reviewing the findings from cross-cultural studies shows that while samples tend to obtain similar gratifications from using Facebook, cultural factors play a main role in altering the value of these gratifications. For instance, $\mathrm{Ku}$, Chen, \& Zhang's (2013) study reveals that the main gratifications American users obtained from Facebook, in order, are relationship maintenance, entertainment, information, sociability, and fashion. Meanwhile, Taiwanese users' most commonly obtained gratifications, in order, are entertainment and relationship maintenance, information, sociability, and fashion. It is worth noting that there are no major differences among the findings of studies that have been conducted within the same culture over time, such as studies with American samples (i.e., Raacke \& Bonds-Raacke, 2008; Urista, Dong \& Day, 2009; Hunt, Atkin \& Krishnan, 2012; Kwon, D’Angelo, \& McLeod, 2013). Their findings reveal similar gratifications, varying by two or three gratifications within each study.

All of the above studies have focused on the empirical aspects of uses and gratification theory and neglected the theoretical parts of the theory. They did not attempt to contribute to the conceptual foundations of the theory by reviewing or suggesting further modifications to its assumptions. Focusing on the revealed gratifications obtained from Facebook, it appears that in some cases, researchers have used different terms to convey similar meanings. For example, Joinson (2008) and Alhabash et al. (2012) used the term 'social investigation' in their findings to indicate that Facebook has been used to satisfy the need to gather information about others. Zhang, Tang \& Leung (2011) and Alemdar \& Köker (2013) used the term 'social surveillance', while Urista, Dong \& Day (2009) used 'curiosity about others' and Bumgarner (2007) used the term 'voyeurism' to convey the same meaning. While these findings show that uses and gratifications researchers have been flexible in assigning terms that are considered suitable to the revealed gratifications, critics have considered such diversity a limitation that might make it difficult to compare results.

A further criticism directed at some studies is the use of a pre-prepared list of gratifications from which to choose (i.e., Bumgarner, 2007; Raacke \& Bonds-Raacke, 2008; Sheldon, 2008; Bonds-Raacke \& Raacke, 2010; Quan-Haase \& Young, 2010; Alhabash, et al. 2012; Jackson \& Wang, 2013). Although clearly this helps to cut down the inclusion of non-appropriate items, it may also lead to bias as participants are not free to explain why they use Facebook. A recommended approach to avoid this limitation that could be adopted by future research, is to build the research questionnaire using both items developed in previous studies and information from preliminary focus group sessions with participants from the same population.

Reviewing uses and gratifications studies assisted in guiding the research to avoid known limitations of uses and gratification studies. Rubin (1994) recommended that future uses and gratifications studies should give more attention to cultural significance. However, the review has shown a continued lack of and need for studies from Islamic and conservative cultures. Previous studies have also failed to analyse how participants vary in their involvement with Facebook by looking at patterns of the obtained gratifications to show if, for example, identifiably different groups use Facebook to gratify different needs. Future research should attempt to take a step forward in uses and gratifications research by constructing a typology of the different ways users use Facebook across a range of obtained gratifications. The findings revealed from such an analysis contribute not only to the uses and gratifications field but also to the body of knowledge about the typology of social media users, and strengthen the media and communication research about media usage patterns across users.

\section{Status Updates on Facebook}

Generating and sharing content, particularly the ability to share status updates on Facebook, has challenged traditional media sources by enabling individuals to air views and opinions formerly marginalised by corporate 
media (Leung, 2009). Despite being widely utilised by Facebook users (Dang, et al. 2014), few scholars have analysed the content generated by Facebook users in the form of status updates.

Some of the existing studies analyse the linguistic units of the status updates, either by investigating the applicability of speech act theory to users' statuses or analysing semantic patterns (e.g. Carr, Schrock, \& Dauterman, 2012; Ilyas \& Khushi, 2012; Lin \& Qiu, 2013). Others have examined the emotional words mentioned in the status updates, either by using linguistics software to compute the frequency of positive and negative emotional words in participants' status updates or by manually categorising these words as being negative, neutral, or positive (e.g. Lin \& Qiu, 2012; Parkins, 2012; Galioto, Hughes, \& Zuo, 2014; Wang, et al. 2014).

Other scholars have focussed on a specific theme of status updates, such as political or alcohol-related references. For example, several scholars from the political perspective were mainly interested in studying Facebook statuses regarding the 2008 presidential election in the US to understand users' voting behaviour and political engagement (e.g., Fernandes, et al. 2010; Carlisle \& Patton, 2013). They categorised the political statuses based on coding classifications proposed in the previous literature. Similarly, Beullens \& Schepers (2013) focused on how alcohol use is depicted in status updates and photos on Facebook and how Facebook friends respond to alcohol-related status updates. A few studies have widened their scope to identifying and analysing the topics shared in users' Facebook status updates (e.g. Denti, et al. 2012; Wang, Burke, \& Kraut, 2013; Winter, et al. 2014).

Utilising self-reported questionnaires, Denti et al. (2012) surveyed 1011 Swedish Facebook users to examine which activities they consider important; how they express their personalities through sharing status updates, including their status themes and their reasons for updating their statuses; and the relationship between Facebook usage and both self-esteem and well-being. The results reveal that a large majority of respondents indicated that their status updates are typically about both major and positive events in their lives. It was less common to generate updates about private or negative events, relationships, or negative feelings. While the results of this study provided a number of topics of users' status updates, its major limitation is that it based its results on data collected via a self-reported, quantitative questionnaire, which may not reflect the actual diversity of status update topics generated by the sample.

In a content analysis study, Wang, Burke, \& Kraut (2013) utilised Latent Dirichlet Allocation-a statistical generative method that looks for clusters of co-occurring words to discover hidden topics-in order to classify topics from about half a million Facebook status updates and to define which topics receive more feedback from other users. Twenty-five themes of status updates emerged from this analysis: "sleep, food, clothing, home, work, weather/travel, family fun, girlfriend/boyfriend, birthday, Father's Day, sports, politics, love, thankfulness, anticipation, asking for support/prayers, medical, memorial, negativity about people, complaining, thoughts, Christianity, religious imagery, and slang and swearing" (Wang, Burke, \& Kraut, 2013: 32). A major drawback of this study is that Latent Dirichlet Allocation generates topics from the frequently co-occurred words automatically, which may not provide as deep an understanding of these topics as human judges manually annotating a smaller corpus. Latent Dirichlet Allocation also does not differentiate between topic style and substance.

Combining questionnaire and content analysis, Winter et al. (2014) related some of users' self-reported personality traits (i.e., extraversion, narcissism, self-efficacy, need to belong, need for popularity) to their use of Facebook status updates. They administered an online questionnaire to 173 European participants assessing personality variables and Facebook use. Participants were asked to post their last three original status updates (as textual messages) in text fields and each status update was categorised according to the following scheme: depth of self-disclosure, self-promoting content, appropriate content, disclosure of emotions, and topics. To assess the topical dimension of status updates, the authors developed a coding scheme comprised of eight categories: leisure time activities, social life/interpersonal relationships, entertainment, societal issues, work/school/university, congratulations, personal issues, and miscellaneous. The most frequent topics among the analysed status updates were personal issues, followed in order by social life/interpersonal relationships, entertainment, congratulations, leisure time activities, work/school/university, miscellaneous, and societal issues. A major limitation of this study is that participants were asked to post only their last three status updates in the questionnaire. This copy-and paste-procedure may have allowed participants to pre-select their status updates. In addition, using only three statuses for analysis may not adequately reflect the diversity of users' status update themes over time.

The above review indicates that these three studies either investigated a considerable number of status updates utilising a statistical generative method, or investigated a very limited number of status updates manually. Although a statistical generative method such as LDA may enable the researcher to analyse a large amount of data, saving time and effort, such methods still have a number of limitations. For instance, the processes performed by such method are mechanical and fail to provide an in-depth analysis of the meaning of the collected data. They also do not support 
linguistic analysis of Arabic effectively due to the complexity of the morphological structure of Arabic (Arabic words are formed by a process of agglutination). To avoid these limitations, it is recommended that further research will utilise a thematic content analysis method and inductive bottom-up approach in investigating the themes of status updates users generate and share on their Facebook profiles in order to expand the understanding of user-generated content within social media platforms.

\section{Self-Disclosure on Facebook}

The concept of self-disclosure has a long history in social science research. Reno and Kenny (1992) indicated that interest in this phenomenon had its roots in Lewin's (1935) cross-cultural study of the differences between Americans and Germans in their degree of openness with newcomers. Such interest in understanding self-disclosure behaviour was revived thirty years later following the publication of Jourard (1964), which emphasised the role of self-disclosure in personal relationships and in the maintenance of psychological health and personal development. In the 1970s, researchers started to be more interested in understanding the processes involved in self-disclosure. This was reflected in Cozby's (1973) classic definition of self-disclosure as any personal information that someone verbally communicates to someone else. Cozby presented self-disclosure as a process and suggested that this process impinges on both the person who reveals and the person who receives the information.

Around the same time, Altman and Taylor (1973) developed social penetration theory, following the social exchange perspective of Thibaut and Kelley (1959). Instead of focusing on the cyclical process of self-disclosure, they were interested in investigating individuals' levels of disclosed personal information and the role of costs and rewards in determining such disclosure within a definite setting. Their theory assumes that individuals are rational beings, who constantly try to maximise their own rewards and minimise their costs.

Disclosure within social penetration theory is considered as having two dimensions: breadth and depth. Breadth refers to the amount of information individuals reveal about themselves or the number of topics they disclose, while depth refers to the degree of sensitivity of the disclosed information. The theory posits that there is a linear increase in both the breadth and depth of self-disclosure when individuals expect favourable outcomes from the disclosure. The 'onion analogy' is used to explain such increase: individuals start with the outer layers, disclosing basic information about themselves, and when they experience rewards that outweigh this cost, they reveal more sensitive inner layers of their personal information (Altman and Taylor 1973). Based on this analogy, individuals do not reveal sensitive information about themselves and shed these layers all at once. Instead, they tend to maintain protective outer layers around a central core that signifies their inner selves until they obtain rewards that lead them to take the risk of revealing more about themselves.

Since its articulation, several attempts have been made to examine the assumptions of social penetration theory in offline one-to-one communication as well as in one-to-many interactions (e.g., Morton, 1978; Hays, 1985; Hammer \& Gudykunst, 1987; Labianca \& Brass, 2006). Nevertheless, the theory has been criticised for its notion that individuals are rational beings in their one-to-one interactions. Critics argue that individuals are not always rational in evaluating the rewards and costs they experience from disclosing personal information when it comes to intimate interactions (Strom, 2002; Kim \& Yun, 2007). As these criticisms are directed towards the applicability of social penetration theory within one-to-one interactions, it is worth investigating whether individuals tend to be more rational in their self-disclosure behaviour in one-to-many communicational settings.

With the development of internet technologies in general and the diffusion of social media in particular, scholars have transferred their attention to the applicability of this classic offline theory to online settings (Wang et al., 2012). Although social penetration theory was initially proposed to explain self-disclosure in offline settings, scholars have argued that it provides a suitable frame for studying self-disclosure in social media contexts. The theory has been widely used in online social media contexts to examine one-to-one interaction (e.g. Cho, 2010; McEwan, 2011; Kim et al., 2012; Chen \& Sharma, 2013; Limperos et al., 2014) and one-to-many communications (e.g., Thotho, 2010; Tang \& Wang, 2012; Jin, 2013; Olson, 2013).

In addition, several studies have investigated the self-disclosure behaviour of users on Facebook. Some of these have attempted to investigate one or both dimensions of self-disclosure (breadth and depth). Other studies have focused on the relationships between privacy concerns and disclosure. A review of these studies is provided below.

\subsection{Studies Investigating Breadth and/or Depth of Self-Disclosure}

Focusing mainly on the breadth of self-disclosure, Kolek \& Saunders (2008) used quantitative content analysis to examine the disclosure behaviour of 50 identifiable information items among a random sample of American university students' Facebook profiles $(n=464)$. The results of this study revealed that they disclosed a substantial 
proportion of their identifiable information, including contact residence information, course schedules, positive mentions of their university, and images of students drinking alcohol. The study also showed that a leak of the disclosed information to unknown viewers could lead to positive or negative consequences but it did not investigate how participants regarded the potential impacts of such disclosure behaviour or how they would modify their behaviour in light of perceiving such consequences.

Using social penetration theory, Thotho (2010) conducted a cross-cultural content analysis of 500 Kenyans' and Americans' Facebook profiles to compare the breadth of information they disclosed online. The results revealed that users from both cultures tended to disclose their demographic variables, but that Kenyans were more likely to use a self-portrait on their profiles and disclosed more information about their religious and political views. On the other hand, a much higher percentage of Americans revealed their full date of birth and information about their college education, such as college name and years of enrolment. Users from both cultures showed low levels of disclosure of their contact information. Thotho's (2010) study highlighted the role of culture in revealing religious and political affiliations by comparing self-disclosure behaviour between a relatively conservative culture and a more liberal one. While she indicated that her study aimed to adopt the assumptions of social penetration theory, Thotho (2010) did not analyse the disclosed information according to its breadth and depth.

Day (2013) also conducted a cross-cultural study to compare how willing Facebook users are to disclose personal information among a sample from Canada, India, Portugal, Australia, New Zealand, and the United States $(\mathrm{n}=27)$. Although the majority of the sample indicated that they disclosed information about their daily lives, the results showed that they did not share problems relating to personal relationships, health, work or family matters, or their religious beliefs. While this study did not classify the disclosed information according to its sensitivity, the findings demonstrated that users avoided disclosing information related to their problems, which may indicate that users are rational in their decisions about sharing some information and avoiding the disclosure of other information.

Olson (2013) adopted social penetration theory and utilised both questionnaire and focus group methods with American participants to investigate the reasons why users disclose personal information on Facebook and how this affects their self-esteem. Eighty-one of the participants responded to the survey and reported that they disclose their positive qualities on Facebook because this makes them feel good. The 15 focus group participants also indicated that such disclosure on Facebook had a positive effect on their self-esteem. This study confirms the assumption of social penetration theory that individuals tend to disclose more when they expect positive outcomes. Although it demonstrated the relationship between the potential reward users may obtain from Facebook and the breadth of their self-disclosure behaviour, Olson's (2013) study did not determine the depth of self-disclosure or the degree of the sensitivity of the information. Determining the relationship between the rewards and the depth of self-disclosure would provide a comprehensive picture regarding the extent to which these rewards are evaluated by users.

It is notable that the above studies mainly focused on counting the frequency of certain disclosed personal information items on Facebook and neglected others. They also did not distinguish between the levels of the depth of the disclosed information. Such limitations were addressed by Nosko, Wood, \& Molema (2010), who analysed the breadth and depth of information disclosure on Facebook. Using factor analysis, they divided disclosed information items into three broad levels according to their sensitivity: basic personal identifying information, sensitive personal information, and potentially stigmatising personal information. Applying this classification to the disclosed information of 400 randomly selected Canadian Facebook profiles, Nosko, Wood, \& Molema (2010) found that their sample tended to disclose $48.2 \%$ of their basic personal identifying information, $69.8 \%$ of their sensitive personal information, and $45.2 \%$ of their potentially stigmatising personal information.

Ntlatywa, Botha, \& Haskins (2012) applied this classification system to their analysis of self-reported information disclosure as compared with observed information disclosure on Facebook. Their study of 131 South African university students showed that observed information disclosure was in fact $30 \%$ greater than self-reported information disclosure. This indicates that users may not accurately report the information they disclose (given that they were off by nearly a third), with the exception of their friends list, which the only Facebook information item was where the observed information disclosure scored lower than self-reported information disclosure.

Applying Nosko, Wood, \& Molema's (2010) classification to the future research contributes to the understanding of the actual levels of disclosure by Saudi university students. It also facilitates the comparison between the disclosure behaviour of different cultures. Besides providing a comprehensive picture regarding the breadth and depth of the information that users disclose, applying this classification also helps in revealing the extent to which the classification of information sensitivity provided by these Western scholars could be applied to cother cultures. 
Given that other cultures may be sensitive about disclosing personal information in offline settings, it is unknown whether these users would carry this behaviour onto Facebook.

\subsection{Studies on the Relationship between Users' Privacy Concerns and Levels of Disclosure of Personal Information}

Researchers interested in examining the relationship between users' privacy concerns and their level of disclosure of personal information on Facebook have mainly utilised self-report methods and conducted their research with university students. These studies have yielded conflicting results. Some have revealed that students' privacy concerns and information disclosure are negatively correlated. For instance, studies conducted with 210 German university students (Krasnova, et al. 2009); with 122 American university students (Stutzman, Capra, \& Thompson, 2011); with 450 American university students (Tufekci, 2012), and with 77 Canadian university students (Young \& Quan-Haase, 2009) all indicated that students with the greatest privacy concerns disclosed the least information. Studies conducted with Islamic samples also revealed similar results. For instance, studies conducted by Osman \& Abd Rahim (2012) with 30 Malaysian university students and by Mohamed (2011) with 325 Emirati and Egyptian users revealed a negative relationship between online privacy concerns and disclosure of personal information online.

Other studies have noted a privacy paradox - a term proposed by Barnes (2006) to refer to users who claim to be concerned about their online privacy but still disclose a considerable amount of personal information on their profiles. For instance, studies conducted with 50 American university students (Govani \& Pashley, 2005), with 13 American university students (Strater \& Richter, 2007), and with 343 Canadian university students (Christofides, Muise, \& Desmarais, 2009; Maqableh, 2012) revealed that while participants reported awareness of some of the privacy concerns associated with Facebook, they highly disclosed personal information on their Facebook profiles.

A noticeable drawback of the studies that revealed a negative correlation between self-disclosure and privacy concerns online and the studies that demonstrated a privacy paradox among their samples is that they all depended on self-reporting methods to collect their data. According to Ntlatywa, Botha, \& Haskins (2012), one of the shortcomings of studies that utilise self-reporting methods in investigating self-disclosure is that participants may not accurately recall the exact amount of their disclosed personal information, which may lead them to evaluate it in a way that does not match their actual behaviour. Such an outcome has been clearly shown in Ntlatywa, Botha, \& Haskins's (2012) study, which reveals a significant difference between self-reported data regarding disclosed information on Facebook and the data collected from observing the participants' actual Facebook profiles. In order to avoid this limitation, Future research should employ both content analysis methods to accurately analyse the actual data disclosed on users' Facebook profiles and interviews with these users about their privacy concerns regarding information disclosure on Facebook.

\section{Gender Differences in Using Facebook}

Scholars from the human and social sciences (e.g., anthropology, sociology, and psychology) have been drawn to understanding the differences between males and females. From those who provided reviews of the developments in social psychology research on gender differences, Ashmore and Sewell's (1998) comprehensive classification of the research on gender differences into six distinctive phases provides an understanding of the historical roots of social role theory.

According to Ashmore and Sewell (1998), scholars from 1894 to 1936 were mainly interested in investigating gender differences in intelligence. From 1936 to 1954 , the construct of masculinity/femininity as a global personality trait (involving a broad range of abilities, interests, attitudes, traits, behaviours, etc.) captured widespread scholarly attention. From 1954 to 1966, many gender scholars shifted their attention to a new construct - sex role - and focused on development processes to account for how boys and girls were socialised to become men and women. From 1966 to 1974 , the reinforcement principles of learning theory were used to explain gender differences. It was argued that males and females do not behave the same way across all situations; as not all situations have the same rewards and costs for males' and females' actions, they learn through their experience the suitable behaviour for each situation. From 1974 to 1982, scholars began to abandon the unidimensional approach to explaining gender differences and started to oppose concepts of 'masculinity' and 'femininity' with 'androgyneity'. They asserted that having both masculine and feminine qualities (i.e. being 'psychologically androgynous') ensured ideal psychological adjustment.

From 1982 to the present, scholars of gender differences have been shifting their focus to looking at gender as a social construct, arguing that gender-related beliefs and behaviour are rooted in society's categorisation of individuals as male or female. They were interested in the many cultural, organisational, and interpersonal systems associated with this categorisation. Thus, gender difference should be understood in terms of the person in a social context 
(Ashmore \& Sewell, 1998). Eagly's social role theory (1987), also known as sociocultural theory or social structural theory, has made a noteworthy contribution to the literature on gender differences that provides an understanding of gender as a social category. Social role theory assumes that each society has stereotypical gender roles based on its social categories. Its essential argument is that gender differences are mainly due to the adoption of these gender roles that determine suitable qualities and behaviours for males and females in a given society. Such roles are defined as the shared expectations of male and female qualities and behaviours, which are adopted, maintained, and dominated by social norms (Eagly, 1987).

These social roles can be explained through two sets of social norms: descriptive norms, which define the understandings of the characteristics and behaviours that are stereotypically adopted according to social roles, and injunctive norms, which define the understandings of the qualities and behaviours that are stereotypically accepted or criticised. Thus, while descriptive norms lead individuals to look to the characteristics and behaviours of those of their own gender to decide the suitable way to behave in a specific situation, injunctive norms serve as guidelines to which qualities and behaviours elicit approval or disapproval from others (Cialdini, Kallgren, \& Reno, 1991). Together, descriptive and injunctive norms assist in assuring males' and females' compliance to their traditional social roles, since deviations would result in unfavourable social outcomes (Luhaorg \& Zivian, 1995).

With the rising popularity of Facebook, scholars have increasingly attempted to investigate gender differences in its usage. This section reviews the gender differences that have emerged in the existing literature regarding obtained gratifications, status updates, and self-disclosure behaviour.

Reviewing the literature about gratifications obtained from Facebook and status updates reveals that while the majority of previous studies did not reveal any gender differences (e.g., Quan-Haase \& Young, 2010; Zhang, Tang \& Leung, 2011; Beullens \& Schepers, 2013; Carlisle \& Patton, 2013; Dhaha \& Igale, 2013; Ku, Chen \& Zhang, 2013; Yang \& Brown, 2013; Galioto, Hughes, \& Zuo, 2014; Wang, et al. 2014), a few studies did show gender differences among Facebook users in some aspects. Details of these differences are shown in Table 2.

Table 2. Studies investigating gender differences in the facebook-obtained gratifications and status updates

\begin{tabular}{|c|c|c|c|c|c|c|}
\hline Authors & Year & Nation & Methods & Participants & $\begin{array}{c}\text { Males' } \\
\text { Gratifications } \\
\text { Status Updates } \\
\end{array}$ & $\begin{array}{c}\text { Females' } \\
\text { Gratifications } \\
\text { Status Updates }\end{array}$ \\
\hline Joinson & 2008 & $\begin{array}{l}\text { Online } \\
\text { sample }\end{array}$ & $\begin{array}{l}\text { Online } \\
\text { questionnaire }\end{array}$ & $\begin{array}{l}241 \text { (80 males, } \\
161 \text { female) }\end{array}$ & - & $\begin{array}{l}\text { For social } \\
\text { connection }\end{array}$ \\
\hline $\begin{array}{l}\text { Raacke \& } \\
\text { Bonds-Raacke }\end{array}$ & 2008 & USA & Questionnaire & $\begin{array}{l}116 \text { ( } 53 \text { males, } \\
63 \text { females) }\end{array}$ & $\begin{array}{l}\text { For gratifying } \\
\text { their dating needs } \\
\text { and to learn about } \\
\text { events }\end{array}$ & - \\
\hline $\begin{array}{l}\text { Park, Kee, \& } \\
\text { Valenzuela }\end{array}$ & 2009 & USA & $\begin{array}{l}\text { Online } \\
\text { questionnaire }\end{array}$ & $1715^{*}$ & - & $\begin{array}{l}\text { For obtaining } \\
\text { information }\end{array}$ \\
\hline $\begin{array}{l}\text { Gülnar, Balcı, \& } \\
\text { Çakır }\end{array}$ & 2010 & Turkey & Questionnaire & $\begin{array}{l}500(282 \\
\text { males, } 218 \\
\text { females })\end{array}$ & $\begin{array}{l}\text { For narcissism } \\
\text { and } \\
\text { self-expression }\end{array}$ & $\begin{array}{l}\text { For relationship } \\
\text { maintenance and } \\
\text { for seeking } \\
\text { information }\end{array}$ \\
\hline Haferkamp et al. & 2012 & Germany & $\begin{array}{l}\text { Online } \\
\text { questionnaire }\end{array}$ & $\begin{array}{l}106 \text { (54 males, } \\
52 \text { females) }\end{array}$ & $\begin{array}{l}\text { To look at others' } \\
\text { profiles to find } \\
\text { friends }\end{array}$ & $\begin{array}{l}\text { For searching for } \\
\text { information and } \\
\text { for comparing } \\
\text { themselves with } \\
\text { others }\end{array}$ \\
\hline Denti et al & 2012 & Sweden & Questionnaire & $\begin{array}{l}1011(335 \\
\text { males, } 676 \\
\text { females) }\end{array}$ & - & $\begin{array}{l}\text { For relationship } \\
\text { maintenance, for } \\
\text { keeping in touch } \\
\text { with family and } \\
\text { friends, and for } \\
\text { writing about } \\
\text { feelings and }\end{array}$ \\
\hline
\end{tabular}




\begin{tabular}{|c|c|c|c|c|c|c|}
\hline Authors & Year & Nation & Methods & Participants & $\begin{array}{c}\text { Males' } \\
\text { Gratifications } \\
\text { Status Updates }\end{array}$ & $\begin{array}{c}\text { Females' } \\
\text { Gratifications } \\
\text { Status Updates }\end{array}$ \\
\hline & & & & & & relationships \\
\hline Parkins & 2012 & Australia & $\begin{array}{l}\text { Content } \\
\text { analysis }\end{array}$ & $\begin{array}{l}50 \text { (25 males, } \\
25 \text { females) }\end{array}$ & - & $\begin{array}{l}\text { For emotional } \\
\text { expression }\end{array}$ \\
\hline $\begin{array}{l}\text { Wang, Burke, \& } \\
\text { Kraut }\end{array}$ & 2013 & USA & \begin{tabular}{l}
\multicolumn{1}{c}{ Latent } \\
Dirichlet \\
Allocation \\
(LDA),
\end{tabular} & $\begin{array}{l}28 \text { (11 males, } \\
17 \text { females) }\end{array}$ & $\begin{array}{l}\text { To share statuses } \\
\text { about public } \\
\text { issues such as } \\
\text { sports and } \\
\text { politics }\end{array}$ & $\begin{array}{l}\text { To share statuses } \\
\text { about } \\
\text { relationships and } \\
\text { personal details }\end{array}$ \\
\hline $\begin{array}{l}\text { Jackson \& } \\
\text { Wang }\end{array}$ & 2013 & $\begin{array}{l}\text { China and } \\
\text { USA }\end{array}$ & Questionnaire & $\begin{array}{l}\text { 491 USA (152 } \\
\text { males, } 339 \\
\text { females) } 401 \\
\text { China (108 } \\
\text { males and } 293 \\
\text { females) }\end{array}$ & - & $\begin{array}{l}\text { For keeping in } \\
\text { touch with } \\
\text { parents, family } \\
\text { members, friends } \\
\text { and people } \\
\text { known but rarely } \\
\text { seen }\end{array}$ \\
\hline Winter et al & 2014 & Germany & $\begin{array}{l}\text { Online } \\
\text { questionnaire }\end{array}$ & $\begin{array}{l}173 \text { (71 males, } \\
102 \text { females) }\end{array}$ & $\begin{array}{l}\text { To share statuses } \\
\text { updates about } \\
\text { entertainment }\end{array}$ & $\begin{array}{l}\text { To share statuses } \\
\text { updates about } \\
\text { personal issues } \\
\text { and } \\
\text { congratulation }\end{array}$ \\
\hline
\end{tabular}

* does not indicate numbers by genders

From Table 2, it can be seen that female Facebook users are more likely than males to obtain gratifications and share status updates related to maintaining relationships, seeking information, comparing themselves with others, and expressing feelings. On the contrary, males use Facebook more than females for dating purposes, self-expression, investigating others, discussing public issues, and entertaining. However, it should be noted that the findings regarding gender differences revealed from a study conducted at a certain time in a certain society may not be similar to those conducted on another society or at a different time. According to Eagly \& Wood (1999), societies today differ in the expected roles assigned to each gender and, thus, it is expected that the differences in the qualities and behaviours of females and males are determined by the extent to which there is a division between their social roles.

Regarding gender differences in online self-disclosure, previous studies conducted among Canadian samples revealed no significant gender differences in the self-disclosure behaviour of Facebook users (e.g., Christofides, Muise, \& Desmarais, 2009; Young \& Quan-Haase, 2009; Nosko, Wood, \& Molema, 2010). On the other hand, American studies have shown that male and female Facebook users differ in their self-disclosure behaviour (e.g., Bond, 2009; Sheldon, 2013). Regarding self-disclosure among Islamic samples, the only known Islamic study was conducted by Mohamed (2011) among Emirati and Egyptian samples. In line with the expected gendered social roles of Arabs, its findings indicated that female users had more privacy concerns, tended to protect their privacy more, and disclosed less information than men.

From the findings of the studies above, it appears that there is a scarcity in the literature regarding studying gender differences among Arab samples in general. Thus, future research may attempt to fill this gap by contributing to the scholarly understanding of the differences between Arab males and females in an online context.

\section{Conclusion}

This paper outlines how an increasing number of scholars have adopted uses and gratifications theory to examine and explain Facebook-obtained gratifications. It presents a review of the relevant literature in the field. These studies generated data based on self-reported methods, such as questionnaires, interviews, and focus groups. They were conducted among users from different countries - mainly Western and East Asian countries - and some involved cross-cultural comparisons. The results obtained from these cross-cultural studies revealed that cultural factors play a role in altering the value of the gratifications obtained from Facebook. The review of these studies indicated that 
there is a gap in literature regarding the gratifications obtained from Facebook by users who belong to Arabic cultures.

Reviewing the literature regarding users' generated content reveals that there is a scarcity of studies investigating Facebook status updates. Previous studies on Facebook status updates have either focused on linguistic units, emotional words mentioned within the status updates, or specific status themes. A few studies analyse a wide range of users' Facebook status update themes, either utilising a statistical generative method to analyse a considerable number of status updates automatically, or analysing a very limited number of users' status updates manually. These studies provide a better understanding of users' online behaviour. Nevertheless, they are mainly based on a deductive top-down approach, which may have caused them to miss some themes that might be revealed through utilising an inductive bottom-up approach.

Research on self-disclosure has focused on the depth and/or breadth of self-disclosure on Facebook or has examined the relationship between users' levels of disclosure and their privacy concerns. While the results of these studies provide valuable information regarding users' disclosure behaviour on Facebook, a major shortcoming of these studies is that they utilise self-reporting methods. As participants may not accurately recall their levels of self-disclosure, this may lead them to evaluate these levels in a way that does not match their actual behaviour. Thus, Nosko, Wood, \& Molema's (2010) classification of the three levels of information disclosed on users' Facebook profiles - basic personal identifying information, sensitive personal information, and potentially stigmatising information- is recommended to be utilised in future research to accurately investigate users' levels of disclosure on Facebook.

Regarding gender differences in the context of Facebook, previous studies reveal that while gender differences have been lessened on Facebook in comparison with offline contexts, some aspects of gender differences remain prevalent online. The literature review showed that the majority of studies in this arena were conducted among Western and East Asian samples and that very few studies have been done in Islamic Arab societies. It seems that little attention has been paid to investigating gender differences in online contexts among users from an Arabic culture.

\section{References}

Alemdar, M. Y., \& Köker, N. E. (2013). Facebook Use and Gratıficatıons: A Study Directed to Determining the Facebook Usage of Generations X and Y in Turkey. Mediterranean Journal of Social Sciences, 4(11), 238-249. https://doi.org/10.5901/mjss.2013.v4n11p238

Alhabash, S., Chiang, Y. H., \& Huang, K. (2014). MAM \& U\&G in Taiwan: Differences in the Uses and Gratifications of Facebook as a Function of Motivational Reactivity. Computers in Human Behavior, 35, 423-430. https://doi.org/10.1016/j.chb.2014.03.033

Alhabash, S., Park, H., Kononova, A., Chiang, Y. H., \& Wise, K. (2012). Exploring the Motivations of Facebook Use in Taiwan. Cyberpsychology, Behavior, and Social Networking, 15(6), 304-311. https://doi.org/10.1089/cyber.2011.0611

Altman, I., \& Taylor, D. A. (1973). Social penetration: The development of interpersonal relationships. Holt, Rinehart \& Winston.

Ashmore, R. D., \& Sewell, A. D. (1998). Sex/gender and the individual. Advanced personality, 377-408.

Balakrishnan, V., \& Shamim, A. (2013). Malaysian Facebookers: Motives and Addictive Behaviours Unraveled. Computers in Human Behavior, 29(4), 1342-1349. https://doi.org/10.1016/j.chb.2013.01.010

Barnes, S. B. (2006). A Privacy Paradox: Social Networking in the United States. First Monday, 11(9).

Beullens, K., \& Schepers, A. (2013). Display of Alcohol Use on Facebook: A Content Analysis. Cyberpsychology, Behavior, and Social Networking, 16(7), 497-503. https://doi.org/10.1089/cyber.2013.0044

Blumler, J. G., \& Katz, E. (1974). The Uses of Mass Communications: Current Perspectives on Gratifications Research. Sage Annual Reviews of Communication Research Volume III.

Bond, B. J. (2009). He Posted, She Posted: Gender Differences in Self-Disclosure on Social Network Sites. Rocky Mountain Communication Review, 6(2), 29-37.

Bonds-Raacke, J., \& Raacke, J. (2010). MySpace and Facebook: Identifying Dimensions of Uses and Gratifications for Friend Networking Sites. Individual Differences Research, 8(1), 27-33. 
Bumgarner, B. A. (2007). You Have Been Poked: Exploring the Uses and Gratifications of Facebook among Emerging Adults. First Monday, 12(11). https://doi.org/10.5210/fm.v12i11.2026

Carlisle, J. E., \& Patton, R. C. (2013). Is Social Media Changing How We Understand Political Engagement? An Analysis of Facebook and the 2008 Presidential Election. Political Research Quarterly, 66(4), 883-895.

Carr, C. T., Schrock, D. B., \& Dauterman, P. (2012). Speech Acts Within Facebook Status Messages. Journal of Language and Social Psychology, 31(2), 176-196. https://doi.org/10.1177/0261927X12438535

Chen, R., \& Sharma, S. K. (2013). Self-disclosure at social networking sites: An exploration through relational capitals. Information Systems Frontiers, 15(2), 269-278.

Cheung, C. M., Chiu, P. Y., \& Lee, M. K. (2011). Online Social Networks: Why Do Students Use Facebook?. Computers in Human Behavior, 27(4), 1337-1343. https://doi.org/10.1016/j.chb.2010.07.028

Chigona, W. (2013). Uses \& Gratifications of Social Network Sites: Case of South Africa. In van Brakel, P. A. (ed.) Proceedings of The 11th Annual Conference on World Wide Web applications, held 10-13 September at Cape Town, South Africa. Cape Town: Cape Peninsula University of Technology, 4-9.

Cho, S. E. (2010). A cross-cultural comparison of Korean and* American social network sites: Exploring cultural differences in social relationships and self-presentation. Rutgers The State University of New Jersey-New Brunswick.

Christofides, E., Muise, A., \& Desmarais, S. (2009). Information Disclosure and Control on Facebook: Are They Two Sides of the Same Coin or Two Different Processes?. Cyber Psychology \& Behavior, 12(3), 341-345.

Cialdini, R. B., Kallgren, C. A., \& Reno, R. R. (1991). A focus theory of normative conduct: A theoretical refinement and reevaluation of the role of norms in human behavior. Advances in experimental social psychology, 24, 201-234.

Cozby, P. C. (1973). Self-disclosure: a literature review. Psychological bulletin, 79(2), 73.

Dang, Y., Zhang, Y., Hu, P. J. H., Brown, S. A., Ku, Y., Wang, J. H., \& Chen, H. (2014). An Integrated Framework for Analyzing Multilingual Content in Web 2.0 Social Media. Decision Support Systems, 61, 126-135.

Day, S. (2013). Self-disclosure on Facebook: How Much Do We Really Reveal?. Journal of Applied Computing and Information Technology, 17(1).

Denti, L., Barbopuolos, I., Nilsson, I., Holmberg, L., Thulin, M., Wendeblad, M., Andén, L., \& Davidsson. E. (2012). Sweden's Largest Facebook Study. Göteborg: Gothenburg Research Institute.

Dhaha, S. S. Y., \& Igale, A. B. (2013). Facebook Usage among Somali Youth: A Test of Uses and Gratifications Approach. International Journal of Humanities and Social Science, 3(3), 299-313.

Dicken-Garcia, H. (1998). The Internet and continuing historical discourse. Journalism \& Mass Communication Quarterly, 75(1), 19-27.

Eagly, A. H. (2013). Sex differences in social behavior: A social-role interpretation. Psychology Press.

Eagly, A. H., \& Wood, W. (1999). The Origins of Sex Differences in Human Behavior: Evolved Dispositions Versus Social Roles. American Psychologist, 54(6), 408-423. https://doi.org/10.1037/0003-066X.54.6.408

Fernandes, J., Giurcanu, M., Bowers, K. W., \& Neely, J. C. (2010). The Writing on the Wall: A Content Analysis of College Students' Facebook Groups for the 2008 Presidential Election. Mass Communication and Society, 13(5), 653-675. https://doi.org/10.1080/15205436.2010.516865

Foregger, S (2008). Uses and Gratifications of Facebook.com. Unpublished PhD thesis. East Lansing, MI: Michigan State University.

Gadekar, R., Kirshnatray, P., \& Gaur, S. (2012). A Descriptive Study of Facebook Uses among Indian Students. Media Asia, 39(3), 140-147. https://doi.org/10.1080/01296612.2012.11689930

Galioto, A. V., Hughes, J. L., \& Zuo, C. (2014). An Investigation of Status Posts and Happiness of Facebook Users. Undergraduate Research Journal for the Human Sciences, 13(1). 
Govani, T., \& Pashley, H. (2005). Student Awareness of the Privacy Implications When Using Facebook. Unpublished Paper Presented at the "Privacy Poster Fair" at the Carnegie Mellon University School of Library and Information Science, 9. Retrieved 21 December 2016, from http://lorrie.cranor.org/courses/fa05/tubzhlp.pdf

Gülnar, B., Balcı, Ş., \& Çakır, V. (2010). Motivations of Facebook, You Tube and Similar Web Sites Users. Bilig, 54, 161-184.

Haferkamp, N., Eimler, S., Papadakis, A., \& Kruck, J. (2012). Men are from Mars, Women are from Venus? Examining Gender Differences in Self-Presentation on Social Networking Sites. Cyberpsychology, Behavior, and Social Networking, 15(2), 91-98. https://doi.org/10.1089/cyber.2011.0151

Hammer, M. R., \& Gudykunst, W. B. (1987). The influence of ethnicity and sex on social penetration in close friendships. Journal of Black Studies, 17(4), 418-437.

Hays, R. B. (1985). A longitudinal study of friendship development. Journal of personality and social psychology, 48(4), 909.

Hew, K. F., \& Cheung, W. S. (2012). Use of Facebook: A Case Study of Singapore Students' Experience. Asia Pacific Journal of Education, 32(2), 181-196. https://doi.org/10.1080/02188791.2012.685560

Hunt, D., Atkin, D., \& Krishnan, A. (2012). The Influence of Computer-Mediated Communication Apprehension on Motives for Facebook Use. Journal of Broadcasting \& Electronic Media, 56(2), 187-202.

Ilyas, S., \& Khushi, Q. (2012). Facebook Status Updates: A Speech Act Analysis. Academic Research International, 3(2), 500-507.

Jackson, L. A., \& Wang, J. L. (2013). Cultural Differences in Social Networking Site Use: A Comparative Study of China and the United States. Computers in Human Behavior, 29(3), 910-921. https://doi.org/10.1016/j.chb.2012.11.024

Jin, S. A. A. (2013). Peeling back the multiple layers of Twitter's private disclosure onion: The roles of virtual identity discrepancy and personality traits in communication privacy management on Twitter. New Media \& Society, $15(6), 813-833$.

Joinson, A. N. (2008). Looking at, Looking up or Keeping up with People? Motives and Use of Facebook. In Proceedings of the SIGCHI Conference on Human Factors in Computing Systems, held 5-10 April at Florence, Italy. New York, NY: ACM Press, 1027-1036.

Jourard, S. M. (1964). The transparent self: Self-disclosure and well-being (No. 17). Van Nostrand.

Karimi, L., Khodabandelou, R., Ehsani, M., \& Ahmad, M. (2014). Applying the Uses and Gratifications Theory to Compare Higher Education Students' Motivation for Using Social Networking Sites: Experiences from Iran, Malaysia, United Kingdom, and South Africa. Contemporary Educational Technology, 5(1), 53-72.

Katz, E. (1959). Mass communications research and the study of popular culture: An editorial note on a possible future for this journal. Studies in public communication, 2, 1.

Katz, E., Blumler, J. G., \& Gurevitch, M. (1973). Uses and gratifications research. The public opinion quarterly, 37(4), 509-523.

Kim, K. H., \& Yun, H. (2007). Cying for me, Cying for us: Relational dialectics in a Korean social network site. Journal of Computer - Mediated Communication, 13(1), 298-318.

Kim, S. J., Bickart, B. A., Brunel, F. F., \& Pai, S. (2012). Can your business have 1 Million friends? Understanding and Using Blogs as one-to-one mass media.

Kim, Y., Sohn, D., \& Choi, S. M. (2011). Cultural Difference in Motivations for Using Social Network Sites: A Comparative Study of American and Korean College Students. Computers in Human Behavior, 27(1), 365-372.

Kolek, E. A., \& Saunders, D. (2008). Online Disclosure: An Empirical Examination of Undergraduate Facebook Profiles. NASPA Journal, 45(1), 1-25. https://doi.org/10.2202/0027-6014.1905

Krasnova, H., Günther, O., Spiekermann, S., \& Koroleva, K. (2009). Privacy Concerns and Identity in online Social Networks. Identity in the Information Society, 2(1), 39-63. https://doi.org/10.1007/s12394-009-0019-1

Ku, Y. C., Chen, R., \& Zhang, H. (2013). Why Do Users Continue Using Social Networking Sites? An Exploratory 
Study of Members in the United States and Taiwan. Information \& Management, 50(7), 571-581.

Kumar, R., \& Thapa, D. (2015). Social media as a catalyst for civil society movements in India: A study in Dehradun city. new media \& society, 17(8), 1299-1316.

Kwon, M. W., D’Angelo, J., \& McLeod, D. M. (2013). Facebook Use and Social Capital: To Bond, to Bridge, or to Escape. Bulletin of Science, Technology \& Society, 33(1-2), 35-43. https://doi.org/10.1177/0270467613496767

Limperos, A. M., Tamul, D. J., Woolley, J. K., Spinda, J. S., \& Sundar, S. S. (2014). "It's Not Who You Know, but Who You Add:" An investigation into the differential impact of friend adding and self-disclosure on interpersonal perceptions on Facebook. Computers in Human Behavior, 35, 496-505.

Lin, H., \& Qiu, L. (2013). Two Sites, Two Voices: Linguistic Differences between Facebook Status Updates and Tweets. In Rau, P. (Ed.), Proceedings of $5^{\text {th }}$ International Conference, CCD 2013 Cross-Cultural Design: Cultural Differences in Everyday Life, held 21-26 July at Las Vegas, NV, USA.

Lin, H., Fan, W., \& Chau, P. Y. (2014). Determinants of Users' Continuance of Social Networking Sites: A Self-Regulation Perspective. Information \& Management, 51(5), 595-603. https://doi.org/10.1016/j.im.2014.03.010

Luhaorg, H., \& Zivian, M. T. (1995). Gender role conflict: The interaction of gender, gender role, and occupation. Sex Roles, 33(9), 607-620.

McEwan, B. (2011). Hybrid engagement: How Facebook helps and hinders students' social integration. In Higher Education Administration with Social Media (pp. 3-23). Emerald Group Publishing Limited.

McQuail, D. (1984). With the benefit of hindsight: Reflections on uses and gratifications research. Critical Studies in Media Communication, 1(2), 177-193.

Mohamed, A. (2011). Online Privacy Concerns among Social Networks' Users. Cross-Cultural Communication, 6(4), 74-89.

Morton, T. L. (1978). Intimacy and reciprocity of exchange: A comparison of spouses and strangers. Journal of Personality and Social Psychology, 36(1), 72.

Nosko, A., Wood, E., \& Molema, S. (2010). All about Me: Disclosure in Online Social Networking Profiles: The Case of FACEBOOK. Computers in Human Behavior, 26(3), 406-418. https://doi.org/10.1016/j.chb.2009.11.012

Ntlatywa, P., Botha, R. A., \& Haskins, B. (2012). Claimed vs Observed Information Disclosure on Social Networking Sites. Information Security for South Africa, 1-6. https://doi.org/10.1109/ISSA.2012.6320443

Olson, A. M. (2013). Facebook and social penetration theory (Doctoral dissertation, Gonzaga University).

Osman, F. Y., \& Abd Rahim, N. Z. (2012). Self-disclosure and Social Network Sites Users' Awareness. In the proceedings of the 2nd International Conference on Research and Innovation in Information Systems, held in 23-24 November at Kuala Lumpur, Malaysia.

Pai, P., \& Arnott, D. C. (2013). User Adoption of Social Networking Sites: Eliciting Uses and Gratifications through a Means-End Approach. Computers in Human Behavior, 29(3), 1039-1053. https://doi.org/10.1016/j.chb.2012.06.025

Park, N., Kee, K., \& Valenzuela, S. (2009). Being Immersed in Social Networking Environment: Facebook Groups, Uses And Gratifications, and Social Outcomes. CyberPsychology \& Behavior, 12(6), 729-733.

Parkins, R. (2012). Gender and Emotional Expressiveness: An Analysis of Prosodic Features in Emotional Expression. Pragmatics and Intercultural Communication, 5(1), 46-54.

Patra, S. K., Gadekar, R., \& Krishnatray, P. (2013). Users' Gratification, Self-Schema and Facebook Behaviour: A Study of Selective Young Facebook Users. Media Watch, 4(1), 84-94.

Quan-Haase, A., \& Young, A. L. (2010). Uses and Gratifications of Social Media: A Comparison of Facebook and Instant Messaging. Bulletin of Science, Technology \& Society, 30(5), 350-361. https://doi.org/10.1177/0270467610380009 
Raacke, J., \& Bonds-Raacke, J. (2008). MySpace and Facebook: Applying the Uses and Gratifications Theory to Exploring Friend-Networking Sites. CyberPsychology \& Behavior, 11, 169-174. https://doi.org/10.1089/cpb.2007.0056

Reno, R. R., \& Kenny, D. A. (1992). Effects of self - consciousness and social anxiety on self - disclosure among unacquainted individuals: An application of the social relations model. Journal of Personality, 60(1), 79-94.

Rubin, A. M. (1983). Television uses and gratifications: The interactions of viewing patterns and motivations. Journal of Broadcasting \& Electronic Media, 27(1), 37-51.

Rubin, A. M. (1984). Ritualized and instrumental television viewing. Journal of communication, 34(3), 67-77.

Rubin, A. M. (1994). Media uses and effects: A uses-and-gratifications perspective. In Bryant, J. and Zillman, M. Hillsdale (Eds.), Media Effects: Advances in Theory and Research (pp. 417-436). NJ: Erlbaum.

Rubin, A. M. (2009). Uses and gratifications: An evolving perspective. The Sage Handbook of media processes and effects, 147-159.

Ruggiero, T. E. (2000). Uses and gratifications theory in the 21st century. Mass communication \& society, 3(1), 3-37.

Sheldon, P. (2008). The Relationship between Unwillingness-to-Communicate and Students' Facebook Use. Journal of Media Psychology: Theories, Methods, and Applications, 20(2), 67. https://doi.org/10.1027/1864-1105.20.2.67

Sheldon, P. (2013). Examining Gender Differences in Self-disclosure on Facebook versus Face-to-Face. The Journal of Social Media in Society, 2(1), 89-106.

Strater, K., \& Richter, H. (2007). Examining Privacy and Disclosure in a Social Networking Community. In Proceedings of the 3rd symposium on Usable Privacy and Security, held 18-20 July at Carnegie Mellon University in Pittsburgh, PA, USA. https://doi.org/10.1145/1280680.1280706

Strom, B. (2002). Communicator virtue and vice: Neglected constructs of relational communication?. Atlantic Journal of Communication, 10(1), 84-103.

Stutzman, F., Capra, R., \& Thompson, J. (2011). Factors Mediating Disclosure in Social Network Sites. Computers in Human Behavior, 27(1), 590-598. https://doi.org/10.1016/j.chb.2010.10.017

Tang, J. H., \& Wang, C. C. (2012). Self-disclosure among bloggers: Re-examination of social penetration theory. Cyberpsychology, Behavior, and Social Networking, 15(5), 245-250.

Thibaut, J. W., \& Kelley, H. H. (1959). The social psychology of groups. New York: John Wiley.

Thotho, S. W. (2010). Information Disclosure on Facebook: A Content Analysis of American and Kenyan User Profiles. Unpublished dissertation. Muncie, IN: Ball State University.

Tosun, L. P. (2012). Motives for Facebook Use and Expressing "True Self" on the Internet. Computers in Human Behavior, 28(4), 1510-1517. https://doi.org/10.1016/j.chb.2012.03.018

Tufekci, Z. (2012). Facebook, Youth and Privacy in Networked Publics. Month, 148, 36-37.

Urista, M. A., Dong, Q., \& Day, K. D. (2009). Explaining Why Young Adults Use Myspace and Facebook through Uses and Gratifications Theory. Human Communication, 12(2), 215-229.

Wang, N., Kosinski, M., Stillwell, D. J., \& Rust, J. (2014). Can Well-Being be Measured Using Facebook Status Updates? Validation of Facebook's Gross National Happiness Index. Social Indicators Research, 115(1), 483-491. https://doi.org/10.1007/s11205-012-9996-9

Wang, Q., Woo, H. L., Quek, C. L., Yang, Y., \& Liu, M. (2012). Using the Facebook group as a learning management system: An exploratory study. British Journal of Educational Technology, 43(3), 428-438

Wang, Y. C., Burke, M., \& Kraut, R. E. (2013). Gender, Topic, and Audience Response: An Analysis of User-Generated Content on Facebook. In Mackay, W. (Ed.), Proceedings of the SIGCHI Conference on Human Factors in Computing Systems held 27 April-2 May at Paris, France.New York, NY: ACM, 31-34. https://doi.org/10.1145/2470654.2470659 
Wang, Z., Tchernev, J. M., \& Solloway, T. (2012). A Dynamic Longitudinal Examination of Social Media Use, Needs, and Gratifications among College Students. Computers in Human Behavior, 28(5), 1829-1839. https://doi.org/10.1016/j.chb.2012.05.001

Whiting, A., \& Williams, D. (2013). Why People Use Social Media: A Uses and Gratifications Approach. Qualitative Market Research: An International Journal, 16(4), 362-369. https://doi.org/10.1108/QMR-06-2013-0041

Wimmer, R. D., \& Dominick, J. R. (2013). Mass media research. Boston, MA: Wadsworth

Winter, S., Neubaum, G., Eimler, S. C., Gordon, V., Theil, J., Herrmann, J., Meinert, J., \& Krämer, N. C. (2014). Another Brick in the Facebook Wall: How Personality Traits Relate to the Content of Status Updates. Computers in Human Behavior, 34, 194-202. https://doi.org/10.1016/j.chb.2014.01.048

Xu, C., Ryan, S., Prybutok, V., \& Wen, C. (2012). It Is Not For Fun: An Examination of Social Network Site Usage. Information \& Management, 49(5), 210-217. https://doi.org/10.1016/j.im.2012.05.001

Yang, C. C., \& Brown, B. B. (2013). Motives for Using Facebook, Patterns of Facebook Activities, and Late Adolescents' Social Adjustment to College. Journal of Youth and Adolescence, 42(3), 403-416. https://doi.org/10.1007/s10964-012-9836-x

Young, A., \& Quan-Haase, A. (2009). Information Revelation and Internet Privacy Concerns on Social Network Sites: A Case Study of Facebook. In Proceedings of The Fourth International Conference on Communities and Technologies, held 25-27 June at Penn State University, Park, PA, USA. https://doi.org/10.1145/1556460.1556499

Zhang, Y., Tang, L., \& Leung, L. (2011). Gratifications, Collective Self-Esteem, Online Emotional Openness, and Trait-like Communication Apprehension as Predictors of Facebook Uses. Cyberpsychology, Behavior, and Social Networking, 14(12), 733-739. https://doi.org/10.1089/cyber.2010.0042 